\section{Creating Regional Coherence}

Paul Murdin, the President of the European Astronomical Society, summarises the society's activities. A founder member and the EAS Vice-President at the start, he works in the UK's newly established Particle Physics \& Astronomy Research Council.

Like the particle physicists, astronomers have been scientifically driven to use larger and larger facilities. The reason for this trend in particle physics arises from the desire to create a new experimental environment of higher and higher energies. By contrast, astronomy, being an observational science, needs larger telescopes or ones in new wavebands. It does not attempt to alter its natural experiments, but to see them in more detail to better understand them. As a matter of the scale of the costs, in both cases the result has been an ever greater internationalization of the two sciences. This has been the underlying reason for the creation in Europe of major astronomical facilities such as the European Space Agency's scientific space programme, the European Southern Observatory, the Canary Islands' Observatories, and the European Very Long Base-line Interferometry networks.

In spite of the existence of these major regional astronomical enterprises, European astronomers have seemed to lack the stronger regional coherence of physicists. The recently established European Astronomical

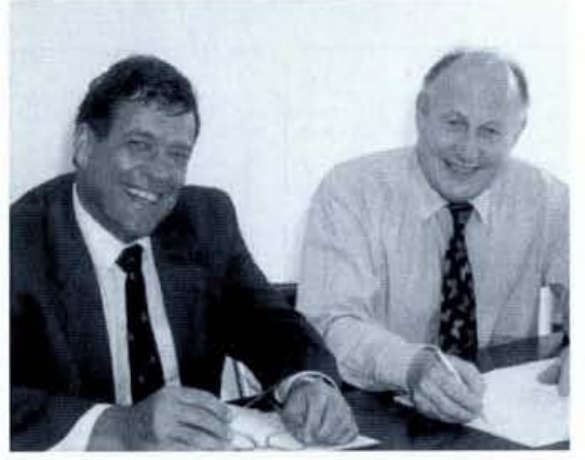

Paul Murdin, on the left, with Martin Huber who chairs the EPS Astrophysics Division.
Society (EAS) had its origins in a desire to do something about this. European members of the International Astronomical Union had noticed how emerging astronomical areas like the Pacific rim and South America, not to mention a well-established area like North America, had been developing strong regional identities in the 1970s and 1980s and wanted similar advantages.

At the same time Europe overall was developing an economic and political cohewished to develop an organizational stance. Thus, the EAS was founded in 1991. This was, of course, at a time when the central and eastern European countries were turning westwards following the collapse of the USSR, and the astronomers of these nations, particularly, embraced the EAS with enthusiasm. By 1994 the EAS has 1500 members, half from the former Soviet Union and its allies.

In the future, the EAS will continue particularly to concern itself with matters on the European level. A question which it is beginning to address is the European resource in trained astronomical personnel. It is no longer adequate to take a national view of such issues, in view of the increasing mobility of European scientists against the background of national differences. Some countries, such as Britain and Germany, have identified an aging population of physical scientists, the rapid expansion of higher education in the 1960 s having clogged up the system against any new intake, which therefore emigrated to the USA. This is complemented by later expansion in recently developing astronomical economies such as Spain's, and complicated by the very recent emigration of young astronomical talent from Russia and the Ukraine. Furthermore, the bulge of aging astronomers in Britain and Germany will soon leave the system. Predicting what could sion, towards which astronomers in Europe happen is obviously a European issue. What then are the overall demographics of the astronomical population in Europe as a whole? What, therefore, are the career prospects for young European astronomers?

Behind such questions lie even more fundamental ones, such as the right balance between the investment in central large-scale facilities, and the brainpower with which to exploit what these facilities can tell us. Will the convergence of physicists and astronomers continue in European science (as so fruitfully in the recent past in respect of particle physicists and cosmologists, and as proposed for the future in ESA missions such as STEP - to extend tests of the Equivalence Principle by 7 powers of 10 - and LISA to detect gravitational waves)? What is the best form of the links between physics and astronomy, as far as both the training of astronomers and the practice of astronomy are concerned?

In a short article I cannot attempt answers to such broad issues; however I can predict that the EAS will play its part in developing policies on all such questions of concern to European astronomers.

\section{EUROPEAN \\ ASTRONOMICAL SOCIETY}

Unlike the EPS, the EAS is based upon the concept of individual membership, although many members pay dues through their national affiliated societies. Virtually all the main professional astronomical societies in Europe have affiliated to the EAS. The main activity of the EAS so far has been to hold annual regional meetings (Liège, Toru and Edinburgh; in 1995 in Catania). It has set up an electronic bulletin board of astronomical jobs as a means to promote opportunities for young astronomers (page 121). Apart from a newsletter, the Society does not intend to add to the proliferation of astronomical journals, but hopes, by measures yet to be finalised, to add to the success of those already in existence. An Emergency Fund was established in 1992 to aid astronomers in the FSU, Bulgaria and Rumania with the purchase of journal subscriptions and also equipment.

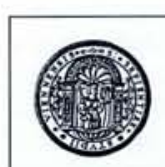

\section{UNIVERSITÄT WIEN}

Am Institut für Experimentalphysik der Formal- und Naturwissenschaftlichen Fakultät der Universität Wien ist die Planstelle eines $/ r$

\section{Ordentlichen Universitätsprofessors/in für Experimentalphysik mit besonderer Berücksichtigung der Experimentellen Festkörperphysik}

ab sofort wiederzubesetzen.

Insbesonders Frauen mit entsprechender Qualifikation mögen sich bewerben. Der/die Stelleninhaber/in soll das Fach Experimentalphysik in Forschung und Lehre vertreten und an den Lehraufgaben der Physikalischen Institute (Anfängervorlesung) im allgemein üblichen Ausmaß mitwirken. Bei der Forschung wird eine Beteiligung an den am Institut vertretenen Gebieten Nukleare Festkörperphysik und/oder Nichtmetallische Festkörper erwartet. U. a. steht dem Institut ein Neutronendreiachsenspektrometer in Saclay zur Verfügung.

Bewerbungen mit den üblichen Unterlagen (Lebenslauf, Darstellung des wissenschaftlichen bzw. beruflichen Werdeganges, Schriftenverzeichnis, Darlegung der Lehrerfahrung) unter Beifügung der fünf wichtigsten

Publikationen werden bis zum 1. Dezember 1994 erbeten an den

Dekan der Formal- und Naturwissenschaftlichen

Fakultät Universität Wien, Dr. Karl Lueger-Ring 1, A-1010 Wien

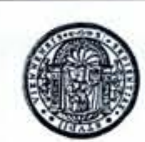

\section{UNIVERSITÄT WIEN}

Am Institut für Theoretische Physik der Formal- und Naturwissenschaftlichen Fakultät der Universität Wien ist die Planstelle eines/r

\section{Ordentlichen Universitätsprofessors/in für Theoretische Physik mit besonderer Berücksichtigung der Mathematischen Physik (Nachfolge Walter Thirring)}

ab Wintersemester 1995/96 wiederzubesetzen.

Das Ordinariat muß Forschung und Lehre in Theoretischer Physik (insbesondere in Mathematischer Physik) im üblichen Ausmaß betreuen. Im Bereiche der Forschung wird enge Kooperation mit dem Internationalen Erwin Schrödinger Institut für Mathematische Physik in Wien erwartet

Bewerbungen sind bis längstens 31. Oktober 1994 an den Dekan der Formal- und Naturwissenschaftlichen Fakultät der Universität Wien, Dr. Karl Lueger Ring 1, A-1010 Wien, zu richten.

Der Dekan:

Fleischhacker 